\section{The Diseases of Occupations *}

\section{A Review by}

\section{RICHARD SCHILLING}

Medical textbooks are nowadays seldom read for both pleasure and enlightenment. As medicine has become increasingly technical and specialized its textbooks have become more difficult to read and are used mostly for reference or during the distasteful preludes to examinations. Donald Hunter's book is an exception. It contains an abundance of knowledge, is highly entertaining in parts, and could be read with considerable interest by those who know nothing about industrial medicine. It is much more than a textbook on occupational diseases, not only because it has chapters on the Industrial Revolution, the social evils and reforms of the nineteenth and twentieth centuries, but because throughout it is flavoured with historical facts, and passages from fiction, sometimes irrelevant but always entertaining. It is an artist's impression of industrial medicine, lacking the balance and perhaps the accuracy of a textbook compiled by several authors but gaining immeasurably in its readability and therefore in its contribution to medicine because it is one man's work, painted in vivid colours and not in dull, respectable pastel shades.

There are many examples to illustrate its artistic character. A few will be mentioned. In the section on marble, a limestone harmless to the lungs as a dust, there is an illustration of Michelangelo's beautiful statue of David in Carrara marble, and an account of the Marble Arch, first built by order of George IV in the gardens of Buckingham Palace. When the Palace had to be enlarged because Queen Victoria had such a large family, it was moved to the Cumberland Gate of Hyde Park. "And then, widening of the road left it stranded in its present position amid a surge of traffic." Six pages are devoted to the development of railways in Britain and contain a descriptive passage from Dickens' Dombey and Son of the building of the great cutting from Camden Town to Euston in London. There are accounts of the addiction to cocaine of Halstead, one of the greatest surgeons of North America, after experimenting with it as an anaesthetic ; of illiterate James Brindley building the Bridgewater Canal; and of blind John Metcalf making new roads in Yorkshire and Lancashire.

All these stories and many others have little to do with diseases of occupations and indeed may irritate the technically minded who want facts to pass examinations or help in their work. But they are fascinatingly written and a similar approach used in ward rounds and out-patients undoubtedly explains the author's great success as a clinical teacher who imparts unforgettably to students his knowledge of history, fiction, and clinical medicine.

The opening chapters give a refreshingly unfamiliar account of some of the historical and economic back-

* The Diseases of Occupations. By Donald Hunter. (Pp. $\mathrm{xv}+1046 ; 438$ illustrations. £5 5s.) London: English Universities Press. 1955. ground of all types of work in ancient and modern times. It is not the approach of the specialist in industrial medicine who usually confines his interest to occupations in factories and mines but of the general physician who observes facts of clinical significance in every type of occupation. Who else would have considered the hazards of workers in chemical and bacteriological laboratories, of gardeners and veterinary surgeons, of the European red pepper industry, of the nomadic way of life, or of living on the Asiatic steppes?

The account of the social reforms of the nineteenth century is a series of excellent descriptions of the attempts to correct the social evils of that time. But with the chapter on the health of the worker in the twentieth century it is too disjointed and not sufficiently discursive to be a serious contribution to the history of industrial medicine ; and there are some gaps which must be filled in a later edition. There is no mention of the Factories Act of 1948 and no clear picture of the appointed factory doctor who remains the backbone of factory medical supervision in Great Britain.

There is no doubt that the most valuable chapters are those on subjects best known to the author: the toxicology of the metals and their compounds, the aliphatic and aromatic carbon compounds, the noxious gases, and occupational diseases due to infections and physical agents.

The part concerning the occupational case history should be read by every medical student and doctor. One particular paragraph suffices to illustrate the importance which the author attaches to a detailed history :

"Ask him the name of his trade, the processes employed, the tools used, and the substances handled. The name he gives to his job may be an obvious euphemism. If he tells you he's a salvage officer he means a dustman, and if he says vermin exterminator he means rat catcher.... Whether he be a fish hobbler, getter-up charger, head sinker, nobbler, muckerout, swadge sawyer, teazer, trolloper or whammeler, he will respond to your detailed questions if only you are firm and tactful and show appreciation of his skill.

"The name of an occupation may mislead you, for different names are used for the same or closely similar processes in different parts of Great Britain. ... In coal-mining the shale or rock between the seams of coal is drilled or blasted by miners who may work in separate shifts from the coal-getters. The man who does this type of work is usually called a hardheader in South Wales, a brancher in Somerset, a stoneman in Durham, a ripper in Yorkshire, and a brusher in Kent. More than sixty names have been given to the variants of this job."

The sections already mentioned and those dealing with the pneumoconioses, occupational cancers, and diseases of the skin are well referenced, and give good accounts with plenty of illustrations of some of the best published clinical work. However, there are some surprising omissions. For example, no reference is made to Craw's work on pneumoconiosis among the haematite miners of Cumberland (Craw, 1947). There is nothing about the important recent research work on bladder tumours in rubber and dyestuff workers indi- 
cating new carcinogens and that exposure to aniline itself does not cause bladder tumours (Association of British Chemical Manufacturers, 1953). Reference might also have been made to Hueper's comprehensive review (1953) of the occupational cancers and to the recent work on accident proneness by Adelstein (1952) and Arbous and Kerrich (1951).

There are some less important errors in an otherwise carefully written work. As some Scots know only too well, England's population is not 50 million persons ; and Charles Turner Thackrah, a Leeds physician and one of the great pioneers in industrial medicine, died in 1833 and not in 1832 .

The author has written this book primarily for students, general practitioners, and consultants. It has much to commend it to doctors in general medicine. His advice to industrial medical officers is to consult larger and more detailed books. But there is not one published in this country which deals so comprehensively with the occupational diseases as his own.

Much space is devoted to the prevention of industrial diseases by medical and engineering control which is relatively easy when the causative agent and its mode of action are known. Some of the more complex problems of occupational medicine, for example chronic chest disease, coronary artery disease, and the rheumatic disorders are only likely to be elucidated by clinical research workers using epidemiological methods. It would be uncharitable to criticize this book for its lack of reference to epidemiology since it has been written primarily for those who treat the sick, and epidemiology is not taught as part of clinical medicine in the medical schools of this country.

As a contribution to industrial medicine it is a remarkable achievement and will surely take its place among the few classics written on this subject.

\section{REFERENCES}

Adelstein, A. M. (1952). J. roy. Stat. Soc. A., 115, 354. Arbous, A. C., and Kerrich, J. E. (1951). Biometrics, 7, 340. Association of British Chemical Manufacturers (1953). Papilloma of the Bladder in the Chemical Industry. London.

Craw, J. (1947). In Silicosis, Pneumokoniosis and Dust Suppression in Mines : Proceedings of Conference of the Institution of Mining Engineers and the Institution of Mining and Metallurgy, London, 1947, p. 68

Hueper, W. C. (1953). In The Physiopathology of Cancer, ed. F. Homburger and W. H. Fishman, p. 730. Hoeber, New York

\section{THE JULY (1955) ISSUE}

The July (1955) issue contains the following papers :-

Emphysema and Proteinuria in Men Casting Copper-cadmium Alloys. By J. A. Bonnell.

Appendix : Physico-chemical Examination of the Serum and Urine Proteins in Some Cases of Cadmium Poisoning. By R. A. Kekwick.

An Environmental Study of Casting Copper-cadmium Alloys. By E. King.

Disabling Pneumoconiosis from Limestone Dust. By A. T. Doig.

An Epidemiological Study of Byssinosis Among Lancashire Cotton Workers. By R. S. F. Schilling, J. P. W. Hughes, I. Dingwall-Fordyce, and J. C. Gilson.

The Effect of Cortisone on Established Silicotic Fibrosis in the Lungs of Rats. By E. J. King, C. V. Harrison, and Daphne Attygalle.

Leptospirosis in South-East Scotland. By P. N. Edmunds.

Energy Cost of Some Industrial Operations. By D. Turner.

Cutting Oils and Squamous-cell Carcinoma. Part I : Incidence in a Plant with a Report of Six Cases. By Ernest Mastromatteo.

Cutting Oils and Squamous-cell Carcinoma. Part II : An Experimental Study of the Carcinogenicity of Two Types of Cutting Oils. By J. P. W. Gilman and S. D. Vesselinovitch.

Rheumatism in Coal-miners. Part III : Occupational Factors. By J. S. Lawrence.

A number of copies are still available and may be obtained from the Publishing Manager, British Medical Association, Tavistock Square, W.C.1, price 12s. 6d. 